http://doi.org/10.35784/iapgos.2816

\title{
ON THE CAPACITY OF SOLAR CELLS UNDER PARTIAL SHADING CONDITIONS
}

\section{Mateusz Bartczak}

Wroclaw University of Technology, Chair of Electronic and Photonic Metrology, Wrocław, Poland

Abstract. A photovoltaic system under uniform illumination conditions has only one global maximum power point, but the same panel in the case of partial shading conditions can have more maxima on the power-voltage curve. The author presents the simulations and results of measurements on a photovoltaic system under different lighting conditions. Impact of nonlinear capacitance on the shape of the response to excitation in the form of a load is presented. The paper also describes which photovoltaic cell parameters influence the shape of the $C$-V curve. The author proposes to analyze the voltage response of the system in order to extract information about partial shade condition.

Keywords: MPPT, PSC, partial shading, I-V curve, solar capacitance, solar cell model

\section{O POJEMNOŚCI OGNIW FOTOWOLTAICZNYCH W WARUNKACH CZĘŚCIOWEGO ZACIEMNIENIA}

Streszczenie. System fotowoltaiczny $w$ warunkach równomiernego oświetlenia ma tylko jeden globalny punkt mocy maksymalnej, ale ten sam panel w przypadku warunków częściowego zacienienia może mieć więcej maksimów na krzywej moc-napięcie. Autor przedstawia symulacje i wyniki pomiarów systemu fotowoltaicznego w różnych warunkach oświetlenia. Przedstawiono wpływ pojemności nieliniowej na ksztalt odpowiedzi na wzbudzenie w postaci obciązenia. W artykule opisano również jakie parametry ogniwa fotowoltaicznego wplywaja na ksztalt krzywej C-V. Autor proponuje analizę odpowiedzi napięciowej systemu w celu wydobycia informacji o stanie częściowego zacienienia.

Slowa kluczowe: MPPT, PSC, częściowe zacienienie, krzywa I-V, pojemność ogniw fotowoltaicznych, jednodiodowy model ogniwa fotowoltaicznego

\section{Introduction}

Recently renewable energy has caught more and more scientific research attention due to popularity of solar power, prosumer activities. The process of replacing conventional electricity production systems with photovoltaic systems (PV) has progressed in recent years, due to characteristics such as: environmentally friendly, reliability, renewability, etc. Every year there is an increase in the share of electricity produced by photovoltaic panels compared to other energy sources [7] In recent years, a lot of low-cost maximum power point (MPP) trackers are emerging. In these devices we can find different types of DC-DC converters, a cross section of these converters can be found in these articles [5, 16]. Simplified diagram of the maximum power point tracker (MPPT) is presented in Fig. 1.

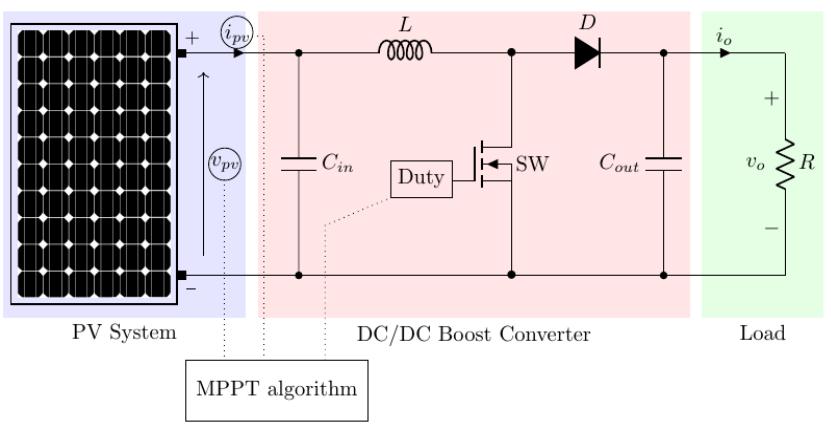

Fig. 1. Schematic diagram of PV System with MPPT

The PV System from Fig. 1 is an assembly of photovoltaic cells and bypass diodes. Temperature, illumination, partial shade condition (PSC), number of bypass diodes, the way individual PV cells are connected, have the greatest influence on the I-V characteristics of a PV system [11]. The single diode solar cell equivalent model is presented in Fig. 2. This model is very well known in the scientific literature, there are a number of papers describing the individual effects of the elements of this model on the I-V characteristics [1, 15] and methods of extracting the parameters of this model [14]. This model is commonly used in the design of photovoltaic systems, because it can be used to determine with sufficient accuracy the power delivered by the photovoltaic module to the load. However, for modelling the physical phenomena that occur inside photovoltaic cells, the single diode model is incomplete. It concerns an ideal cell in which the only processes occurring in the semiconductor region are leakage (negligibly small) and diffusion of current carriers, which finds its reference in the diode $d_{1}$.

$$
I=I_{p h}-I_{d 1}\left(e^{\frac{q\left(V-R_{S} I\right)}{n K T}}-1\right)-\frac{V-R_{S} I}{R_{s h}}
$$

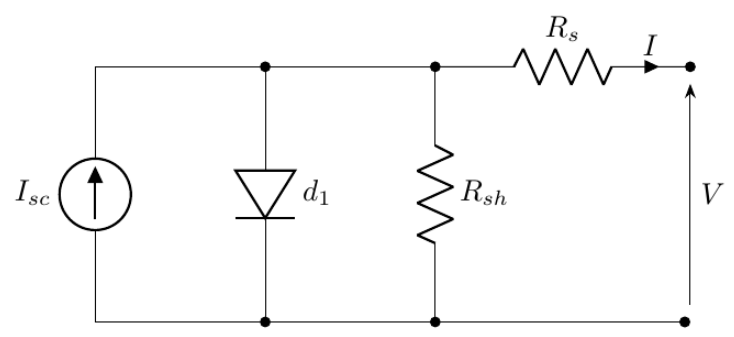

Fig. 2. Solar Cell Single diode model

Publications also include studies on the two-diode model $[3,12]$. The effect of recombination in the space charge region of the junction was considered by including a second diode $d_{2}$ in the circuit, in parallel with diode $d_{1}$. The diode ideality factor (n) for $d_{1}$ is not included in this model. It was assumed to have a constant value equal to 1 for the diffusion component, which corresponds to the absence of recombination phenomenon, making diode $d_{1}$ reflect an ideal photovoltaic cell. The diode $d_{2}$ reflects the recombination component of the dark saturation current. The ideality factor for a $d_{2}$ diode is 2 , because there are no phenomena other than recombination. Equation (2) is showing the relation between diode currents.

$$
I=I_{p h}-I_{d 1}\left(e^{\frac{q\left(V-R_{S} I\right)}{K T}}-1\right)-I_{d 2}\left(e^{\frac{q\left(V-R_{S} I\right)}{2 K T}}-1\right)-\frac{V-R_{S} I}{R_{s h}}
$$




\section{Description of the problem}

Extraction of electrical power from solar photovoltaic (PV) systems under nonuniform irradiance such as partial shading (PSC) is the most challenging task for the solar PV engineers \& researchers. The output power of the solar panel, which was reduced due to shading (since the cells are connected in series, shading one cell will reduce the current in the others), was corrected with a bypass diode [10]. The impact of PSC on the $\mathrm{I}-\mathrm{V}$ characteristic and the $\mathrm{P}-\mathrm{V}$ characteristic is presented in Fig. 4Fig. 5. They have been generated from a single diode model and reflect the three photovoltaic panels with bypass diodes connected to form one photovoltaic system. The connection is shown in Fig. 3. Each module is made of 20 cells connected in series and has bypass diode connected to the output terminals, therefore the total open-circuit voltage is about $35 \mathrm{~V}$.

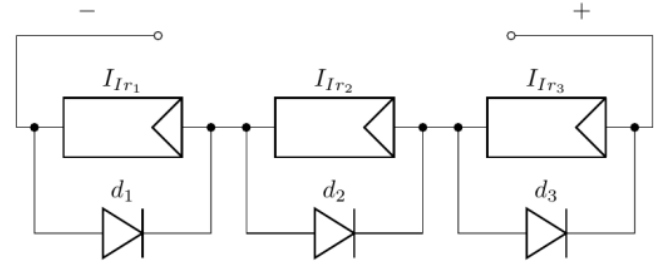

Fig. 3. Bypass diodes connected with solar modules

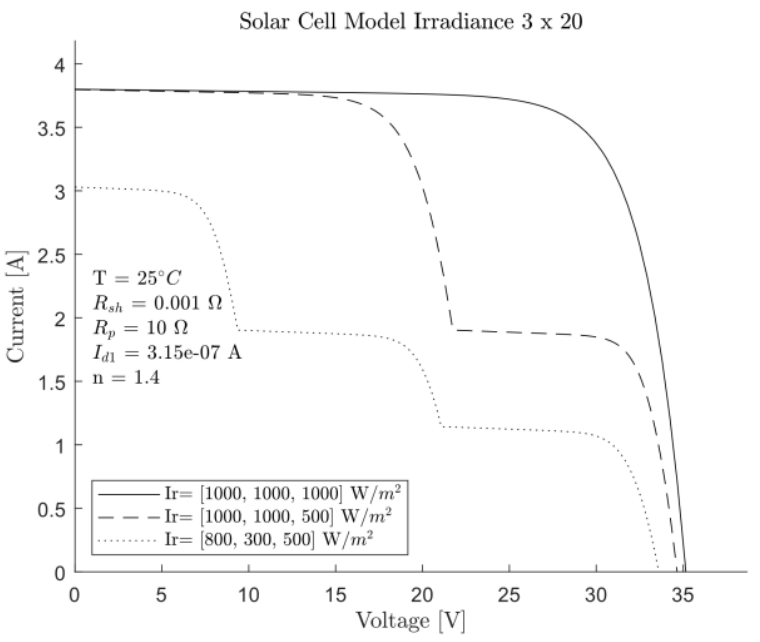

Fig. 4. PSC impact on the PV system I-V characteristic

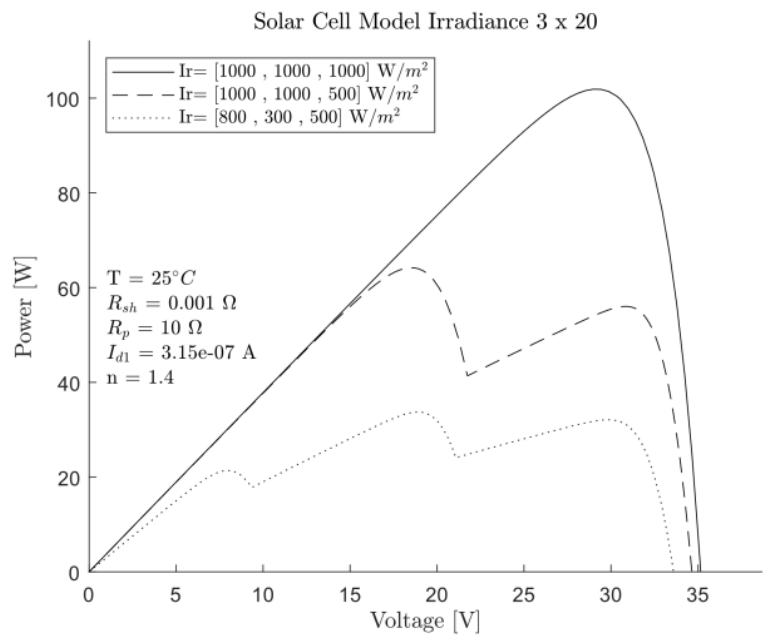

Fig. 5. PSC impact on the PV system P-V characteristic
At non-uniform irradiance conditions local maxima appears on the P-V characteristics which make it difficult for the MPPT controller to search for the maximum power point. There are various types of MPPT techniques used to run PV modules on maximum power. Researchers are constantly creating or improving existing MPPT algorithms. In the research mainstream, algorithms can be divided into couple of groups: classical (Constant Voltage, Perturb \& Observe, Incremental Conductance, etc.), intelligent (Artificial Neural Network, Fuzzy Logic, Sliding Mode Controller etc.), optimization (Particle Swarm Optimization, Cuckoo Search etc.). A review of this techniques is presented in following article [4].

\section{Experiment setup}

One of the classical \& conventional simple MPPT is Fractional Short-Circuit Current (FSCC) algorithm. This method assumes that the ratio of $I_{m}$ (current at MPPT) to $I_{s c}$ (short-circuit current) is approximately a constant value, hence $I_{m}$ and $I_{s c}$ have a linear relationship (3), where of $\mathrm{K}$ is approximately given in the interval $K \in(0.78,0.92)$ [8].

$$
I_{m}=K \cdot I_{s c}
$$

In the context of Fig. 1, if the Short-Circuit Current MPPT type algorithm performs the measurement of current $I_{s c}$, it must close the SW key, then measure the current flowing from the PV System. In the next step the algorithm calculates the $I_{m}$, based on it, sets the corresponding duty cycle on the SW gate. Then the key is opened and the voltage returns to the $V_{p v}$ returns to voltage determined by load resistance. In this paper, the author measures the return of this voltage to the operating voltage at time.

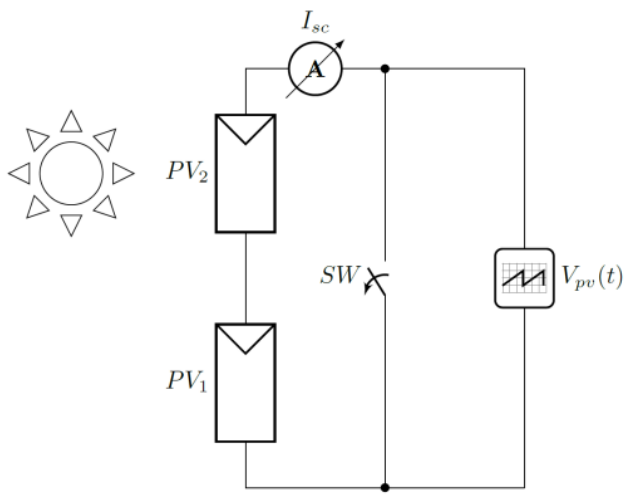

Fig. 6. Simplified schema of measurement setup

Fig. 6 shows a simplified scheme of the measuring system for $V_{p v}(\mathrm{t})$. Two photovoltaic panels were exposed to sunlight. The irradiance of the sunlight was verified using an intensity meter (SOLAR POWER METER TM-206, Accuracy: typically within $\pm 10 \mathrm{~W} / \mathrm{m}^{2}$ or $\pm 5 \%$ ). Additionally, the radiation intensity was confirmed by measuring the $I_{s c}$, because the short-circuit current has linear relation to the solar radiation intensity. $V_{p v}(\mathrm{t})$ has been measured on the oscilloscope (Rigol DS1054Z $50 \mathrm{MHz}, 1 \mathrm{GSa} / \mathrm{sec})$. The data has been collected from two connected in series solar panels (STP010-12/Kb $10 \mathrm{~W}$, $\left.I_{s c}=0.65 \mathrm{~A}, V_{o c}=21.6 \mathrm{~V}\right)$.

\section{Results}

Using a photovoltaic cell model, so as to simulate the voltage return, a linear charging of the capacitor with a current source is expected. The experimental data show a different shape of $V_{p v}(t)$ Fig. 7. The panels had uniform lighting conditions, measurement has been performed for different irradiances. 


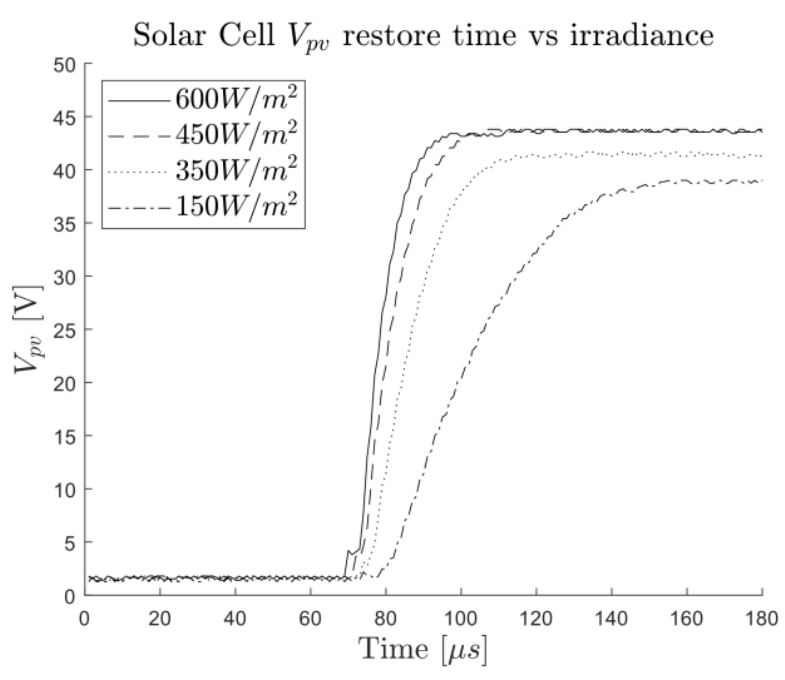

Fig. 7. Restore time of two connected in series STP010-12/Kb $10 \mathrm{~W}$ panels

Measurements were also made for non-uniform lighting conditions. When the lighting conditions between two panels are significantly different, one is fully illuminated the other is almost darkened, a fold will start to form on the system response as shown in Fig. 8. The voltage response has this shape, because it is the sum of the responses from the two panels.

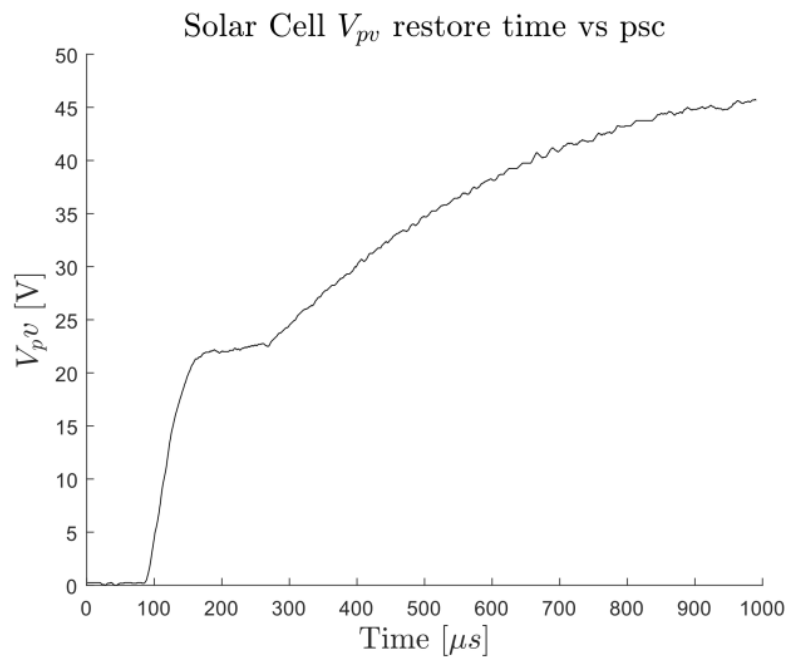

Fig. 8. Output voltage restore time of two connected in series STP010-12/Kb $10 \mathrm{~W}$ panels when one of the panels is $90 \%$ covered by shade

Shape, rise time of the curve are results from the phenomenon of nonlinear capacitance which occurs at the junction of $p-n$ layers. The two layers of $p-n$ junction can be considered as a capacitor [2]. The capacitance can be so expressed as following equation (4).

$$
C=\frac{\varepsilon A}{W}
$$

Figures $9-10$ presents the non-linear capacitance value in relation to cell voltage, figures data have been generated by the use of a computer program SCAPS. This software can be used to the simulation of solar cells based on different materials types. The software allows to solve numerically the Poisson's equation coupled with continuity equations for both charged carrier electrons and holes [6]. Data has been generated for uniform donor and acceptor density in semiconductor layers and assuming the structure has no defects.
Solar Cell C-V vs donor and acceptor density

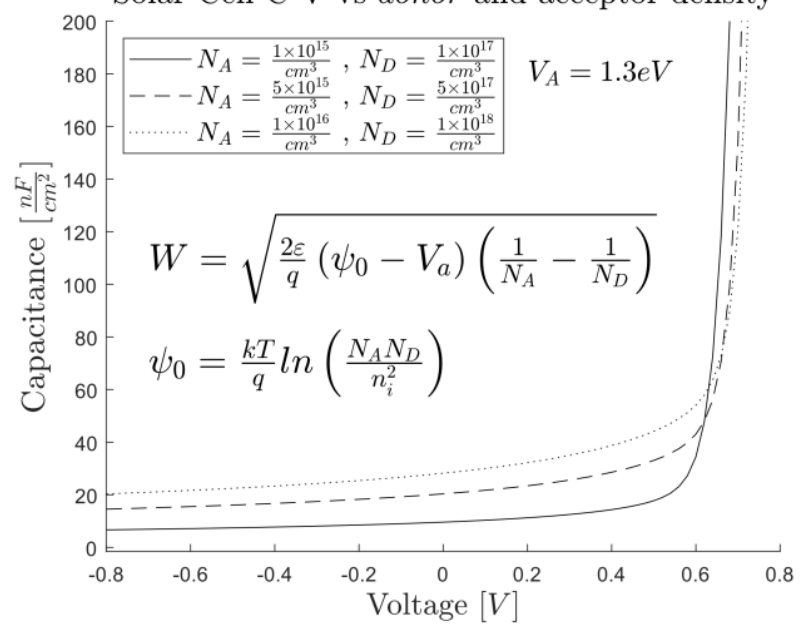

Fig. 9. Solar cell $C$-V vs donor and acceptor density

The doping density of $\mathrm{p}$ and $\mathrm{n}$ layers has also an effect on the capacitance of the silicon solar cell Fig. 9. The impact of electric gap on the nonlinear capacitance is presented on Fig. 10. When the solar cell is illuminated, there is a photogeneration process which drives the recombination and diffusion of electrons. The diffusion induces a charge variation into the solar cell accompanied by a charge in the voltage across the cell. It is this charge variation that induces mainly the capacitance of the solar cell under illumination [2].

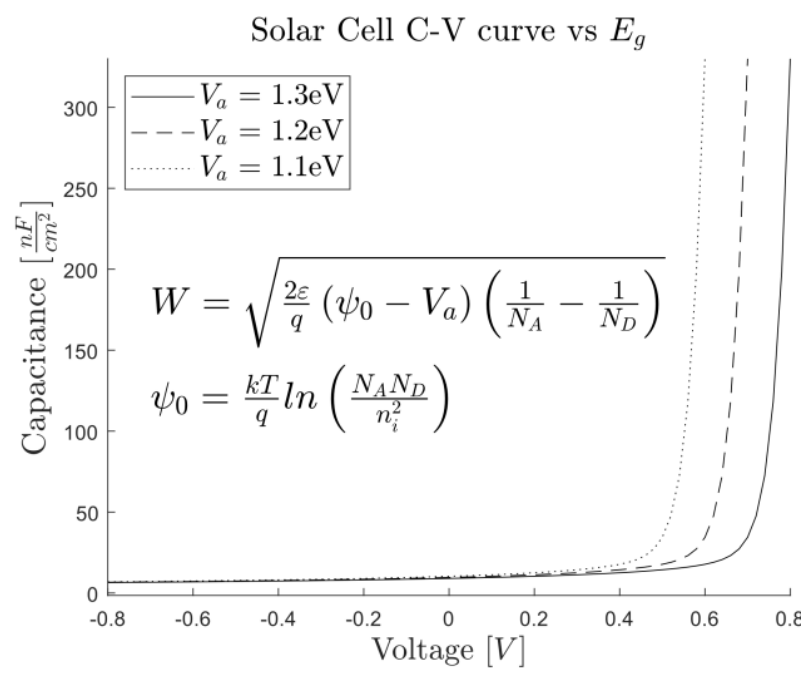

Fig. 10. Solar cell C-V curve vs energy gap of semiconductor

Since the voltage rises Fig. 7Fig. 8 when the SW key Fig. 6 is opened, there is a change in the overall capacitance of the PV System. Capacitance increases as this voltage builds up. When the voltage on the cell is less than $0.6 \mathrm{~V}$, this corresponds to short circuit $\left(I_{s c}\right)$ operation of the cell and the capacity is then lower. It is driven by the massive flow of minority carriers through the junction. However, if the voltage is above $0.6 \mathrm{~V}$ then the cell is closer to open circuit voltage $\left(V_{o c}\right)$. Capacitance increases exponentially, this can be explained by a large storage of carriers in the junction. voltage, the carriers cannot easily move to and cross the junction. A larger number of carriers causes an increase in electrical field, they cannot easily move to and cross the junction. 
Analysing the system response in terms of voltage rise time and shape can give information about the insolation state of the system in particular whether there is a PSC. The detection of partial shading conditions is not a major topic in the literature, authors of [13] are using neural network to obtain shade condition. Using the Fill Factor calculation, partial shading can be distinguished from the uniform shading situation [9].

\section{Conclusions}

The nonlinear capacitance that occurs in photovoltaic systems is worth attention. If there is a need to simulate dynamic load changes and observe voltage changes on a photovoltaic cell, it is worth considering nonlinear capacitance in the photovoltaic cell model. The author proposes an analysis of the voltage response, in terms of changes in shape caused by partial shading of the system. Information about partial shading condition can be valuable from MPPT algorithm point of view, allowing the selection of the type of algorithm. Also, creation of hybrids of MPPT algorithms is possible, for example Fractional ShortCircuit Current (FSCC) algorithm can be combined with Cuckoo Search (CS). The analysis also allows the detection of various defects in the photovoltaic system. The implementation of the voltage rise analysis algorithm does not require drastic changes to the DC-DC converter circuit, the converter has its own capacitance which must be considered.

\section{References}

[1] Azzouzi M. et al.: Modeling of electrical characteristics of photovoltaic cell considering single-diode model. Journal of Clean Energy Technologies 4(6), 2016, 414-420.

[2] Barro F. I. et al.: On the capacitance of crystalline silicon solar cells in steady state. Turkish Journal of Physics 39(2), 2015, 122-127.

[3] Bollipo R. B. et al.: Critical review on PV MPPT techniques: classical, intelligent and optimisation. IET Renewable Power Generation 14(9), 2020, $1433-1452$.

[4] Bollipo R. B et al: Critical review on PV MPPT techniques: classical, intelligent and optimisation. IET Renewable Power Generation 14(9), 2020, 1433-1452.

[5] Bubovich A.: The comparison of different types of DC-DC converters in terms of low-voltage implementation. 5th IEEE Workshop on Advances in Information, Electronic and Electrical Engineering (AIEEE), 2017, 1-4, [http://doi.org/10.1109/AIEEE.2017.8270560].
[6] Burgelman M. et al.: Modelling polycrystalline semiconductor solar cells. Thin solid films 361, 2000, 527-532.

[7] Cozzi L. et al: World Energy Outlook 2020 - IEA, Organization for Economic Co-operation and Development (OECD) / IEA, Paris, France, 2020 [https://www.iea.org/reports/world-energy-outlook-2020] (available: 10.10.2021).

[8] Danoune M. B. et al: Study and performance analysis of three conventional MPPT algorithms used in photovoltaic applications. International Conference on Communications and Electrical Engineering (ICCEE). IEEE, 2018.

[9] Davies L. et al.: Automatic detection and characterization of partial shading in PV system. IEEE 7th World Conference on Photovoltaic Energy Conversion (WCPEC) (A Joint Conference of 45th IEEE PVSC, 28th PVSEC \& 34th EU PVSEC), 2018

[10] Fadliondi F. et al.: Bypass diodes for improving solar panel performance. International Journal of Electrical and Computer Engineering 8(5), 2018, 2703.

[11] Franjo P., Virtič P.: Power production comparison of photovoltaic modules. Przegląd Elektrotechniczny 90(12), 2014, 284-287 [http://doi.org/10.12915/pe.2014.12.72].

[12] Humada A. M. et al.: Solar cell parameters extraction based on single and double-diode models: A review. Renewable and Sustainable Energy Reviews 56, 2016, 494-509.

[13] Mekki H. et al.: Artificial neural network-based modelling and fault detection of partial shaded photovoltaic modules. Simulation Modelling Practice and Theory 67, 2016, 1-13.

[14] Rhouma M. B. H. et al.: A simple method for extracting the parameters of the PV cell single-diode model. Renewable Energy 113, 2017, 885-894.

[15] Shannan N. M. et al.: Single-diode model and two-diode model of PV modules: A comparison. IEEE International Conference on Control System, Computing and Engineering, 2013.

[16] Singh S. P. et al.: Performance comparison of MPPT techniques using Cuk converter for photovoltaic energy conversion system. 3rd International Conference on Computational Intelligence \& Communication Technology (CICT), 2017, 1-6 [http://doi.org/10.1109/CIACT.2017.7977369].

\section{M.Sc. Eng. Mateusz Bartczak \\ e-mail: mateusz.bartczak@pwr.edu.pl}

Ph.D. student and employee of Wroclaw University of Technology. At this moment assistant professor of Department of Electronic and Photonic Metrology. His scientific interest is mainly focused on renewable energy sources in particular photovoltaic cells, PV modules, DC/DC converters. He works on algorithms for maximum power point tracking and modeling of photovoltaic systems.

http://orcid.org/0000-0003-4459-4173

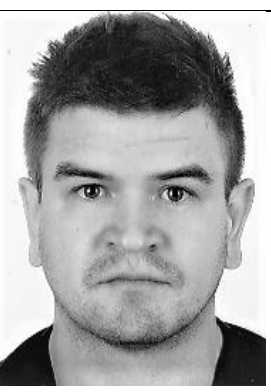

otrzymano/received: 10.11.2021 przyjęto do druku/accepted: 15.12 .2021 